\title{
The Substitution Principle Revisited
}

Jakub Stejskal, Freie Universität Berlin, jakub.stejskal@,fu-berlin.de

(accepted version, forthcoming in Source: Notes in the History of Art)

In their Anachronic Renaissance, Alexander Nagel and Christopher Wood identify two principles upon which, in fifteenth-century Europe, a work of art might establish its validity or authority: substitution and performance. ${ }^{1}$ One of the recurring themes in the responses to this much debated book has been its indebtedness to Hans Belting's Bild und Kult. ${ }^{2}$ Specifically, it has been routinely suggested that the dual schema of substitution and performance follows Belting's dualism of the medieval cult of the image and the modern aesthetic system of art. This, I submit, is not just a mistake, but also prevents from evaluating perhaps the book's most ambitious contribution to arthistorical theory on its own merits. An analysis of the structure of the claims made by Nagel and Wood brings to light that the two concepts—substitution and performance-do not play the same role as the conceptual pair of Bild and Kunst in Belting's influential work.

In the reactions to Anachronic Renaissance, a lot of attention has been paid — and rightly so — to the substitution principle. This proved to be one of the most highlighted as well as most controversial topics of the book. ${ }^{3}$ The criticisms of "substitutability" range from its being too vague, ${ }^{4}$ too schematic, ${ }^{5}$ to its distorting its subject because of an alleged postmodern bias. ${ }^{6}$ What ended up more

1 Alexander Nagel and Christopher S. Wood, Anachronic Renaissance (New York: Zone Books, 2010), $13,31$.

2 Hans Belting, Bild und Kult: Eine Geschichte des Bildes vor dem Zeitalter der Kunst (Munich: Beck, 1990).

3 The principle was already discussed in Christopher S. Wood, Forgery, Replica, Fiction: Temporalities of German Renaissance Art (Chicago: University of Chicago Press, 2008), 25-60.

4 Frank Fehrenbach, review of Anachronic Renaissance, by Alexander Nagel and Christopher S. Wood, caa.reviews, March 8, 2011, doi:10.3202/caa.reviews.2011.30.

5 Gerhard Wolf, review of Anachronic Renaissance, by Alexander Nagel and Christopher S. Wood, Art Bulletin 94, no. 1 (2012): 139.

6 Walter Cupperi, “Introduction: Never Identical; Multiples in Pre-Modern Art?," in Multiples in Pre-Modern Art, ed. 
detrimental to its reception, however, was its association early on with Belting's work. According to Gerhard Wolf, "if one sees the authors' substitutional model as the medieval one and their performative one as that of the Renaissance, it is clear that Anachronic Renaissance follows a structure analogous to the shift from Bild to Kunst in Bild und Kult." For Frank Fehrenbach, "it is not difficult to recognize Belting's opposition of 'art' versus 'cult' behind" the concepts of performance and substitution. ${ }^{8}$ Keith Moxey observed that "the imaginative elaboration of the concepts of 'substitutional' and 'performative' [is derived] ultimately from" Bild und Kult. ${ }^{9}$ Katherine Hunt even suggested that Nagel and Wood applied Belting's ideas "somewhat uncritically." ${ }^{10}$ In a recent authoritative overview of the research into the epistemic role of images in early modernity, Alexander Marr notes Nagel and Wood's indebtedness to Belting as a matter of course, proving that the association has achieved the status of received wisdom. ${ }^{11}$

Hunt's remark notwithstanding, commentators usually hasten to add that Nagel and Wood do not just slavishly apply Belting's schema, but that they provide a more nuanced approach that complicates the somewhat over-simplifying narrative of a switch from the veneration of the divine through image to a secularized aesthetic experience of art. ${ }^{12}$ What remains unchallenged is that when Nagel and Wood speak of substitution and performance, they roughly refer to the same processes as Belting when he discusses Bild and Kunst, though the claim is nowhere to be found

Walter Cupperi (Zurich: Diaphanes, 2014), 20.

7 Wolf, review of Anachronic Renaissance, 137.

8 Fehrenbach, review of Anachronic Renaissance.

9 Keith Moxey, review of Anachronic Renaissance, by Alexander Nagel and Christopher S. Wood, Contemporaneity: Historical Presence in Visual Culture 1 (2011): 153, doi:10.5195/contemp.2011.35.

10 Katherine Hunt, "Substitution and Subversion: Two Paths through the Renaissance," Art History 35, no. 4 (2012): 842.

11 Alexander Marr, “Knowing Images,” Renaissance Quarterly 69, no. 3 (2016): 1006.

12 E.g., Jeffrey Hamburger, "Hans Belting's Bild und Kult: eine Geschichte des Bildes vor dem Zeitalter der Kunst, 1990,” Burlington Magazine 153, no. 1294 (2011), 44. 
explicitly stated in the book itself. Such a reading misconstrues the distinction Nagel and Wood introduce. In order to get a clearer view of the difference involved, it is important to disentangle two meanings of "substitution" relevant to art history.

Nagel and Wood's principle of substitution, or "of continuity of identity across a succession of substitutions," 13 treats art as a "structural object," with a specific artwork serving as the token of a type. ${ }^{14}$ An art object may be substituted by another material object, provided it partakes of the identity features of the type. These features secure its legitimacy and efficacy as a member of a chain of substitutions usually leading back to a mythical act of creation. By contrast, the principle of performance, or of authorship, traces an artwork's origin to a specific creative gesture and its authority and efficacy rests in its material identity over time and "nonsubstitutability." 15 Under the substitution principle, an icon may have been repainted several times, even replaced altogether, or may have existed in several versions at different places, but all its material occurrences were perceived as true instances of the type, often with no sense of contradiction. This was possible because the icon was perceived both as if it were a relic materially linked to its original appearance and as if it were a piece of writing that may be rewritten any time on a different material without any loss of identity. The principle of substitution under which all the instances of a type are perceived as identical; the lack of means to identify at all precisely (and a lack of interest in doing so) the time and place of origin of specific instances; and the general tendency of removing religious imagery from the flow of secular time made it easier to treat replicas as originals. As Nagel and Wood argue, with the rise of humanist scholarship, with the influx of Byzantine icons that were often taken (mistakenly) to be authentic works of Christian antiquity, and with the emergence of the cult of the Great Artist, the incompatibility of the substitution and the performance principles was becoming growingly apparent with the result that this incompatibility

13 Nagel and Wood, Anachronic Renaissance, 14.

14 Ibid., 12.

15 Ibid., 14, 60. 
itself became the subject of many Renaissance artworks. ${ }^{16}$

On the rare occasions when Nagel and Wood employ Belting's term Bild, they use it in Belting's sense, that is, to describe the power of holy images to make the divine present. ${ }^{17}$ The term does describe a kind of substitution, namely, the potential of a picture to stand in or act on behalf of another body or agency. In his Bild-Anthropologie, Belting identified the substitutive function of images — variously referred to as Verkörperung, Stellvertretung, Ersatz — to be as old as the making of images itself and connected it to the desire to provide the deceased (and by analogy, the absent) with an ersatz-body, contrasting it with the Western identification of mimetic image with a medium of remembrance. ${ }^{18}$ But crucially, that is not the meaning the term "substitution" carries in Anachronic Renaissance.

The concept of substitution Nagel and Wood apply is at a remove from Belting's notion. Instead of asking how art objects become effective, whether as surrogate agents or as aesthetic representations, they ask rather how their acquired authority is sustained through time and space. The performance and the substitution principles offer two patterns of this sustenance, two ways of securing the survival of an established link between an art object and its source of authority. Thus, for example, the "models" of the Holy Sepulcher, which sprang up across Europe in the early centuries of the second millennium played not only the role of memorials and "physical reminders," but also of substitutes, tokens participating on the identity of the type. Only because they could be treated as identical to the Holy Sepulcher could they function as sites of veneration-centers of "virtual pilgrimages." 19 And something similar applies to the Byzantine icons of the Virgin imported to the West in the fifteenth century: Nagel and Wood discuss copies of the supposed original icon painted by St Luke from the Church of Santa Maria del Popolo in Rome being presented as both replicas

16 Ibid., 71, 109-22, 147-58.

17 Ibid., 118, 122.

18 Hans Belting, Bild-Anthropologie: Entwürfe für eine Bildwissenschaft (Munich: Fink, 2001), 143-88.

19 Nagel and Wood, Anachronic Renaissance, 60-61. 
and as authentic works of the evangelist. ${ }^{20}$

In a sense close to how Belting thinks about substitution, already the supposedly genuine St Luke icon in Rome and the Holy Sepulcher in Jerusalem are substitutes, just not in the sense Nagel and Wood have in mind. Because the Holy Sepulcher in Jerusalem was the place of Christ's resurrection, it can stand in for him as the subject of veneration. Because the icon was painted by the evangelist's hand and "from life," it is a relic-like index of the presence of Virgin Mary and thus can stand in for her. ${ }^{21}$ But the substitution principle Nagel and Wood describe does not address this relationship between the absent agency and its representation. ${ }^{22}$ What it addresses is how an art object's identity is secured across time and space. So while the replicas of Madonna del Popolo stood in for what they represented in Belting's sense of substitution, they secured this privileged relationship both by instantiating features of her type (substitution principle) and by their claim to material identity (nonsubstitutability).

In Nagel and Wood's narrative, the growing awareness of the incompatibility between the relic-like character of a supposedly authentic art object like the Madonna del Popolo and its identity secured through substitution was resolved in favor of its relic status: in the end, the involvement of any act of substitution was denied. It is this denial of substitution in favor of performance that has swayed commentators to view Nagel and Wood's narrative through Beltingian lens: the substitutive logic of Bild is superseded by the performative logic of Kunst. But such a reading misses that the authorial performance principle effectively inherits its relying on nonsubstitutability from what can be called 'the relic principle'. ${ }^{23}$ In other words, the medieval principle of relic is the same as the principle of authorial performance of the High Renaissance to the extent that both of them secure the identity of

20 Ibid., 109-15.

21 See Horst Bredekamp, Der Bildakt, 2nd. ed. (Berlin: Wagenbach, 2015), 181, 187, 193.

22 As Wolf also notices in his review of Anachronic Renaissance, 137.

23 "Somewhat surprisingly," adds Fehrenbach in his review of Anachronic Renaissance; but the surprise arrives only when one expects a Beltingian break between substitution and performance. 
an object by its nonsubstitutability. It would then follow that contrary to the Beltingian reading of Anachronic Renaissance, it is not that the performance and substitution regimes coexisted (uneasily) in the Christian West only during the fifteenth century, making it a sort of a buffer zone between the Era of Substitution and the Era of Performance, but rather that something like the performance principle, that is, the relic principle coexisted with the substitution principle in the preceding centuries as well. ${ }^{24}$

As the tension between performance and substitution grew throughout the fifteenth century, Nagel and Wood argue, it became exploited by the Renaissance artists for artistic purposes. Their notorious example is Botticelli's Portrait of Youth Holding an Icon (ca.1480). In this painting, the authors claim, a fourteenth-century icon is inserted into a fifteenth-century panel painting in order to exemplify the different ways of securing authority. If it indeed was placed there by Botticelli or his contemporary - which is far from certain ${ }^{25}$ - it represents a highly self-aware gesture of the nascent artistic culture: the icon serves to exemplify a whole "system of image transition." It is a picture manifested as antique and sustained across time by substitution. It contrasts with the authorial way of securing artistic authority exemplified by the modern-day portrait: not through a chain of substitutions, but by the supreme authorial gesture. Here, we encounter what Nagel and Wood describe - in a move to distance themselves from Belting - as the creation of a retrospective myth of the Bild, the cult image immune to history, as opposed to a modern portrait manifesting its embeddedness in a secular time. ${ }^{26}$ But working against this myth, I would argue, is the painting's celebration of progress, acknowledging at the same time the icon as its predecessor, and thus also as the product of an authorial gesture, stripping it of part of its substitutional magic and anchoring it,

24 Clair Farago and Donald Preziosi's criticism of Nagel and Wood thus misses its target, see their Art Is Not What You Think It Is (Malden, MA: Wiley-Blackwell, 2012), xi-xiii.

25 See Fehrenbach, review of Anachronic Renaissance.

26 Ibid., 128. See also Valentina Hristova, "Pour une lecture intelligible d'Anachronic Renaissance: contenu et critiques," Studiolo, no. 9 (2012), 315. 
as it were, in the secular time. The substitution principle, confronted with the authorial principle, does not vanish, but transforms itself - just like the relic principle morphed into the authorial. Botticelli's painting presents itself not just as a relic of a performance that brought it into the world (the index of the artist's action), but also as an instantiation of a type, of a genre of portraiture for which the inserted icon serves as a venerable predecessor that lends it legitimacy. Granted, situating a painting in a linear historical genealogy is hardly the same thing as placing it in a chain of functionally identical substitutes. What remains, however, is the intention to endow an artifact with authority by identifying it with a class of authoritative objects, in Botticelli's case by constructing a Whiggish history of the progress of portraiture painting.

I have argued that Nagel and Wood do not present just another, if more nuanced, version of Belting's story of the shift away from substitution. First, their use of substitution differs from Belting's in that it describes primarily a model for sustaining the identity and authority of an art object and not the nature of the relationship to what it represents. And second, the transformation narrated by Nagel and Wood could best be described as a change of relation between the substitution and performance principles rather than as a move from one to the other. In the fifteenth century, a sense of the incompatibility between substitution and performance takes shape and becomes a problem for artists to tackle. But that does not mean that some version of both principles was not at play before and perhaps also after this incompatibility became an artistic problem. As models of securing authority for an artwork, both seeing an artwork as a relic of a performance that brought it into the world (the index of an action) and seeing it as an instantiation of a type may prove much more general and widespread to be each associated with incompatible artistic cultures that briefly clashed in the fifteenth century before the one succeeded the other. 